
Report Number: CRNI- 822

Health and Biology

This document consists of 15

pages.

Copy $\angle 6 /$ of 167 Series

ISSUED

Contract Ho. W-7405-Eng-26

BIOLOGY DIVISION

THE EFFECT OF $X$ IRRADIATION IN OXYGEN AND IN HYDROGEN AT NORMAL AND POSITIVE PRESSURES ON CHROMOSOME ABERRATION FREQUENCY IN

TRADESCANTIA MICROSPORES

Morman H. Giles, Jr. and Alvin V. Beatty

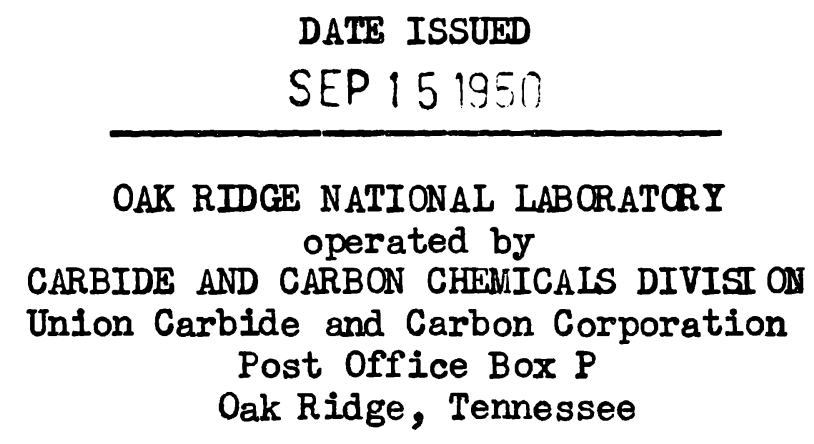


ORIL 822

Health and Biology

\section{Internal Distribution:}

\begin{tabular}{|c|c|c|c|}
\hline $\begin{array}{r}1 \\
2-3 \\
4 \\
5 \\
6 \\
7 \\
8-9 \\
0-13 \\
14 \\
15\end{array}$ & $\begin{array}{l}\text { G. T. Felbeck (C\&CCC) } \\
\text { 706-A Library } \\
\text { 706-B Library } \\
\text { Biology Library } \\
\text { Health Physics Library } \\
\text { Metallurgy Library } \\
\text { Training School Library } \\
\text { Central Files } \\
\text { C. E. Center } \\
\text { C. E. Larson }\end{array}$ & $\begin{array}{l}\text { 16. W. B. Humes }(\mathrm{K}-25) \\
\text { 17. } \mathrm{N} \cdot \mathrm{D} \cdot \text { Lavers }(\mathrm{Y}-12) \\
\text { 18. H. I. . Teinberg } \\
\text { 19. E. J. Nurphy } \\
\text { 20. F. C. VonderLage } \\
\text { 21. A. Hollaender } \\
\text { 22. J. S. Felton } \\
\text { 23. J. H. Swartout } \\
\text { 24. H. H. Snell } \\
\text { 25. K. Z. liorgan }\end{array}$ & $\begin{array}{l}\text { 26. F. I. Steahly } \\
27 \cdot \text { H. T. Kelley } \\
\text { 28. D. W. Cardwell } \\
\text { 29. J. H. Gillette } \\
\text { 30. A. S. Householder } \\
\text { 31. N. H. Giles, Jr. } \\
\text { 32. A. V. Beatty } \\
\text { 33. N. J. Skinner } \\
\text { 34. Central Files (O.P.) }\end{array}$ \\
\hline
\end{tabular}

35-42. Argonne National Laboratory

43. Armed Forces Special Neapons Project

44-45. Atomic Energy Commission, Washington

46. Battelle Memorial Institute

47. Brush Beryllium Company

48-55. Brookhaven National Laboratory

56. Bureau of Nedicine and Surgery

57. Bureau of Ships

58-61. Carbide and Carbon Chemicals Division ( $\mathrm{K}-25)$

62-65. Carbide and Carbon Chemicals Division ( $Y-12)$

66. Chicago Operations Office

67. Cleveland irea Office, AEC

68. Columbia University (J. R. Dunning)

69. Columbia University (G. Failla)

70. Dow Chemical Company

71. H. K. Ferguson Company

72-74. General slectric, Richland

75. Harshav Chemical Corporation

76. Idaho Operations Office

77-78. Iowa State College

79. Kansas City Operations Branch

80-81. Kellex Corporation

82-85. Knolls Atomic Power Laboratory

86-88. Ios Alamos Scientific Laboratory

89. Nillinckrodt Chemical Works

90. Massachusetts Institute of Technology (H. Gaudin)

91. Massachuestts Institute of Technology (A. Kaufmann)

92-94. Hound Laboratory

95-96. National Advisory Committee for feronautics

97-98. National Bureau of standards

99-100. Naval Radiological Defense Laboratory

101. New Brunswick Laboratory

102-106. New York Operations Office

107. North American Aviation, Inc.

108. Patent Branch (Washington)

109. RAND Corporation

110. Sandia Laboratory 
Dxternal Distribution:

111. Santa Fe Operations Office

112. Sylvania Electric Products, Inc.

113-127. Technical Information Division (Oak Ridge)

128. UStF, Air Surgeon (Lt. Col. R. H. Blount)

129. USAF, Director of irmament (Captain C. I. Browne)

130-131. UStiF, Director of Research and Development (Col. R. J. líason, F. H. Bruner)

132. ISAF, Figlin Air Force Base (liajor A. C. Field)

133. USAF, Kirtland is Force Base (Col. Ni. F. Cooper)

134. IJSAF, laxwell Air Force Base (Col. F. N. Noyers)

135-136. USHF, NEPA Office

137-138. USAF, Office of Atomic Energy (Col. H. C. Donnelly, H. H. Fickel)

139. USAF, Offutt $A$ ir Force Base (Col. H. R. Jullivan, Jr.)

$\mathrm{Z}_{4} \mathrm{O}$. JSAF, Wright-Patterson Air Force Jase (Rodney Iudenberg)

14l. U. S. Army, Atomic Energy isranch (Lt. Col. h. W. Eetts)

142. U. S. Army, Army Field I'orces (Captain James Kerr)

143. U. S. Army, Commanding General, Chemical Corps Technical Command

(Col. J. H. liaclaughlin through irs. G. S. Benjamin)

144. U. S. firmy, Chief of Ordnance (It. Col. A. R. Del Campo)

145. U. S. Army, Commanding Officer, Watertown Arsenal (Col. C. H. Deitrick)

146. U. S. Army, Director of Operations Research (Dr. Ellis Johnson)

147. U. S. Army, Office of Engineers (HIlen O'Leary)

148. U. S. Army, Office of the Chief Signal Officer (C. T. Clayton through Maj. G. C. Hunt)

149. U. S. Army, Office of the Jurgeon General (Col. W. S. Stone)

150. U. S. Geological Survey (T. N. Nolan)

151. USAF, Director of Plans and Operations (Col. R. L. Applegate)

152. U. S. Fublic Health Service

153. University of California at Los Angeles

154-158. University of California Radiation Laboratory

159-160. University of Rochester

161. University of Washingtor

162-163. Nestern Reserve University

164-167. Westinghouse Electric Company 
THE EFTECT OF $X$ IRRADIATION IN OXYGEN AND IN HYDROGEN AT NORMAL

AND POSIIIVE FRESSURES ON CHRONOSONE ABERRATION FREQUENCI IN

RADESCANTIA MICROSPCRES*

\section{Horman H。Giles, Jro and Alvin V。 Beatty Biolog Division \\ Oak Ridge National Laboratory}

Previous investigations by Giles and Riley (1, 2) have demonstrated a narked effect of oxygen in increasing the frequency of Xoray induced chromosomal aberrations in nicrospores of Tradescantis paludosa. In certain experiments (2), the relation between aberration frequency and percentage of oxygen present during irradiation was studied. Although there was an almost linear increase in aberra* tion frequency between 2 and $27 \%$ oxggen (air), no significant difference was noted between 0\% oxygen (pure helium) and 2\% oxygen (plus 98\% helium)。 Additional experiments have now been performed to reinvestigate the effect of low percentages of oxggen. Further, studies have been made of the effect on aberration frequency of Irradiation in various percentages of oxygen under pressure. Preliminary experiments have also been carried out on the effects of irradiation in hydrogen at normal and positive pressure。 The general methods utilized for $X$ irradiation of inflorescences and subsequent eytological analysis have been described previously (2).

In the experinents designed to reinvestigate the effects of low percentages of oxygen, special attempts were made to remove as much oxygen as possible from the inflorescences before irradiation。 The following procedure was utilized: (1) The inflorescences, after being placed in the gasotight exposure chamber, were subjected to prolonged evacuation. (2) Helium which had been especially freed of any residual oxygen was then introduced into the evacuated exposure chamber. To remove any oxggen the helium was passed slowly through a coil in liquid nitrogen 
and then over copper foll heated to $500^{\circ} \mathrm{C}$ before entering the exposure chamber。 (3) Finaliy, the inflorescences were kept in the dark for an hour before irradiation to facilitate the remoral by respiration of any further oxggen. In addition to the exposures in heliom, irradiations were performed in atmospheres containing 2,50 and $10 \%$ oxygen (plus helivan). The percentages of oxygen in these gas inixtures were accurate (on the basis of analjses furnished by the vendor, the Ohio Chemical and Surgical Equipment Coo) to $0.2 \%$. All experiments wero carried out at room temperature (approximately $25^{\circ} \mathrm{C}$ ) Do increase the statistical reliability of the determinations, a larger number of cells was scored than previously. The data are presented in Table $I_{0}$ The are also plotted in Ig. $I_{0}$ together with the averages of points at higher percentages of oxygen which were obtained in previous experio ments (द्a). These results Iadicate that there is still a substantial yield of aberrations oven in the complete (or neardy complete) absence of oxygen. When oxgen is present durisg iryadition, there is a rapid rise in aberration frequency above this base level. This increase is Iinear between 0 and $10 \%$ oxygen, after which the rise is apparentiy moro gradual, and shows a definite leveling off at around $20 \%$ oxgrgen。

The Irradiation experiments in atmospheres of increasing oxygen concentration just outIined were all performed at normal atmospheric pressure (ca $740 \mathrm{~mm}$ of Hg at Oak Ridge). Since the amourat of dissolved oxygen is directly proportional to pressure, an experinent was designed to tost for an oxggen effect in another way wo by carrying out exposures in which different sets of inflorescences were irradiated in the same oxygen-helism gas intures, but at pressures of $1_{0} 2$ and 3 atmospheres above normal pressure. The sano exposure chamber was used as previously, and the pressure inside the chamber was measwred by means of a standard gauge on the gas cylinder, the accuracy of which was chocked against a mercury manometer over the 
Tabje I

The Iffect of Treadiation in Various Percentages of Oxygen on the

Frequency of Chromosong I Aberrations in Iradescantia Microspores.

AlI IaRar Bxposures of $400 \mathrm{x}$ at $50 \mathrm{r}$ Min.

\begin{tabular}{|c|c|c|c|c|c|}
\hline $\begin{array}{c}\text { Oxygen } \\
\text { percentage }\end{array}$ & $\begin{array}{l}\text { No. } \\
\text { cells }\end{array}$ & $\begin{array}{c}\text { No. } \\
\text { Linterchanges }\end{array}$ & $\begin{array}{c}\text { Interchanges } \\
\text { per cell }\end{array}$ & $\begin{array}{c}\text { Interstitial } \\
\text { deletions }\end{array}$ & $\begin{array}{l}\text { I.D. } \\
\text { per cell }\end{array}$ \\
\hline 0 & 2000 & 234 & $0.234 \pm 0.015$ & 287 & 0.287 t 0.017 \\
\hline 2 & 1200 & $34 \%$ & $0.289 \neq 0.016$ & 394 & $0.328 \pm 0.017$ \\
\hline 5 & 1000 & 427 & $0.427 \pm 0.021$ & 501 & $0.501 \pm 0.022$ \\
\hline 10 & 600 & 364 & $0.607 \div 0.032$ & 453 & $0.755 \div 0.035$ \\
\hline
\end{tabular}




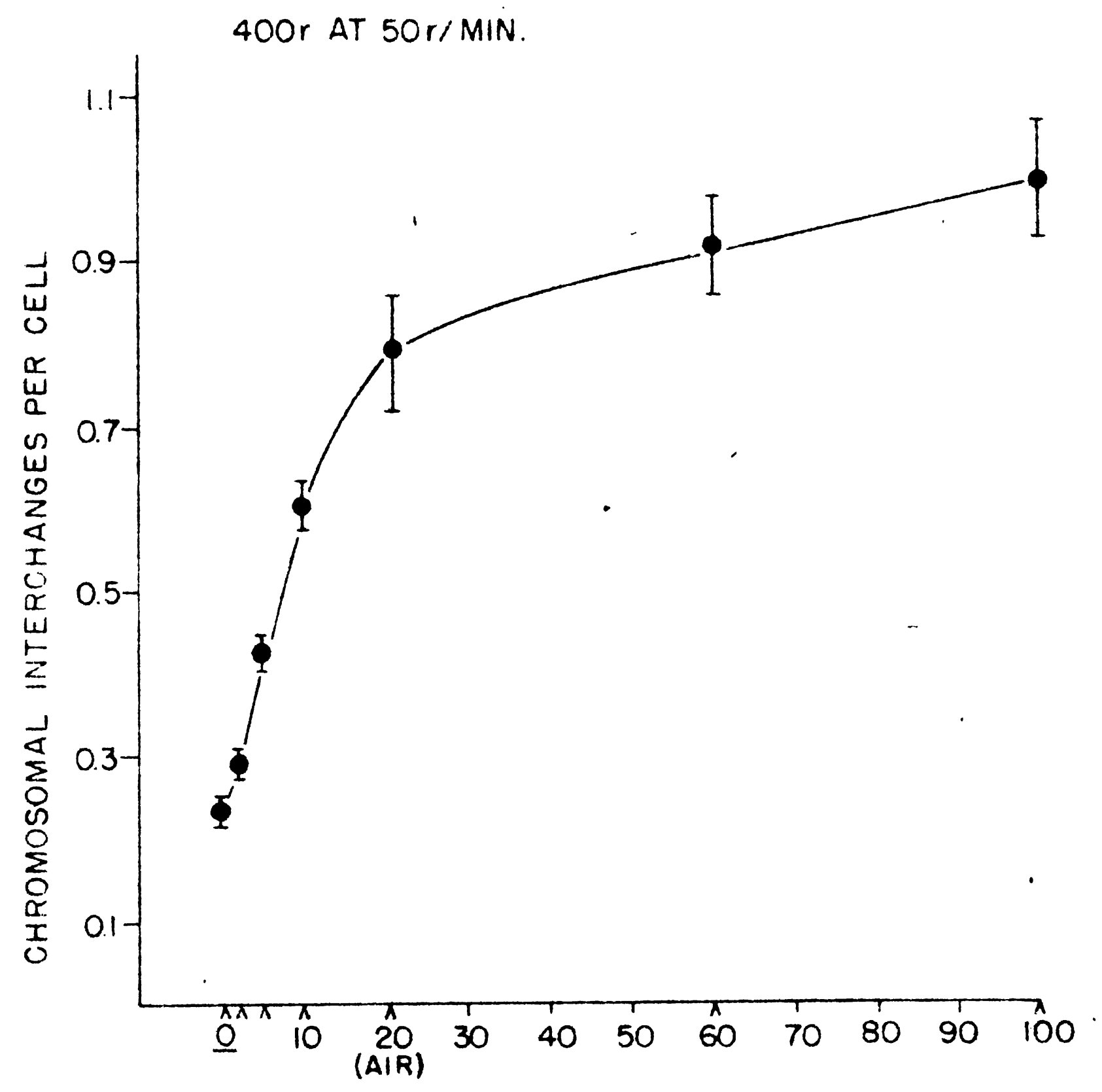

PERCENTAGE OF OXYGEN IN EXPOSURE CHAMBER (NORMAL ATMOSPHERIC PRESSURE)

Fig. I 
range of the first 2 atmospheres above normal. The data for exposures in 5 and 10\% oxygen (plus belinom) are presented in Table 2 , together with results obtained in air and in pure (99.8\%) heliva. The values for two separate experiments in 5\% oxygen at normal pressure have been averaged in the table. During the exposure In compressed alr at 3 atmospheres above normal a small leak developed in the exposure chamber, ard although the pressure gauge did not drop, it is felt that the value for this exposure may not be as reliable as for the other observations.

These results show that there is a marked increase in aberration frequency accomparying increasing pressure lo those experiments in which oxygen was present during Irigadiation. Whor exposwies ocurred in the absence of oxygen (in puit helium) howewer, no increase resulted, indicating that pressure alone, at least within this range, did not lariluence the yield of aberrations. In Fig。 2 the frequencies of chromoscmal iraterehanges at various pressures in 5 and $10 \%$ oxygen have been plotted against the standard curre from Fig。 $I_{0}$ on the assumption that the amount of dissolved oxggon 250 the microspores is directiy proportional to the pressure, and that this value determines the aberration yield at the standard dose of $400 \mathrm{I}$ at $50 \mathrm{I} /$ min. As can be seen from the graph, the agreement with previous results at comparable partial pressures of oxygen is very good。 These results thus support earlier lews that the amount of dissolved oxygen present in cells is an important factor in determing aberration frequeney. They indicate that pressure alone, at least within the range up to 3 atmospheres above normal, does not influence this type of radiationminduced change。

Several different types of evidence (3) support the view of Thoday and Read (4) that the effect of oxygen in Increasing chromosome aberration frequency may result from an indirect action of $\mathrm{X}$ radiation to decompose water with the production of hydrogen peroxide. However, although very Iittle hydrogen peroxide appears to 


\section{Table 2}

Tho Effect of Pressure on the Frequency of XeR ay Induced Chronosomal Aber

rations in Tradescantia licrospores Irradiated in Atmospheres Containing

Various percentages of Oxygen. All Exposures of 400 at 50 in Lino

\begin{tabular}{ccccc}
$\begin{array}{c}\text { Pressure in } \\
\text { exposure chamber }\end{array}$ Noo $\begin{array}{c}\text { No。 } \\
\text { inter } \\
\text { changes }\end{array}$ & $\begin{array}{c}\text { Interchanges } \\
\text { per cell }\end{array}$ & $\begin{array}{c}\text { Noorstitial } \\
\text { deletions }\end{array}$ & $\begin{array}{c}\text { Interstitial } \\
\text { deletions } \\
\text { per cell }\end{array}$ \\
\hline
\end{tabular}

Irradiated in $10 \%$ oxggen (plus $90 \%$ helium)

\begin{tabular}{|c|c|c|c|c|c|}
\hline $\begin{array}{c}\text { Mormal atmospher le } \\
(\mathrm{co} 740 \mathrm{~mm} \mathrm{Hg})\end{array}$ & 800 & 474 & $0.59 \pm 0.027$ & 599 & $0.75 \neq 0.031$ \\
\hline $\begin{array}{l}\text { One atmosphere } \\
\text { above normal }\end{array}$ & 550 & 436 & $0.79 \pm 0.038$ & 563 & $1.02 \pm 0.043$ \\
\hline $\begin{array}{l}\text { Two atmospheres } \\
\text { abowe normal }\end{array}$ & 700 & 584 & $0.83 \pm 0.035$ & 875 & $1.25 \pm 0.042$ \\
\hline $\begin{array}{c}\text { Three atmospheres } \\
\text { above normal }\end{array}$ & 700 & 584 & $0.83 \pm 0.035$ & 732 & i.05 t 0.039 \\
\hline
\end{tabular}

Irradiated in pure helium ( 99.8\%)

NormaI atsospherse

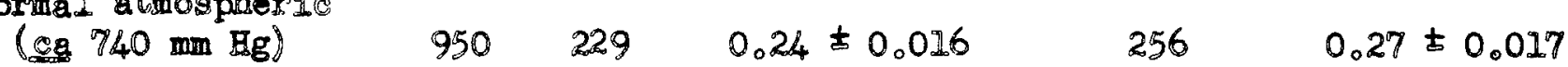

Three atmospheres above normal

1000

223

$0.22 \pm 0.015$

259

$0.26 \pm 0.016$

Irradiated in air

\section{Normàl thosphers (ca $740 \mathrm{~mm} \mathrm{Hg})$}

Three atmospheres above norna?
$1000 \quad 713$
$0.72 \pm 0.027$

780

$0.78 \pm 0.028$

950786

$0.83 \pm 0.030$

994

$2.05 \neq 0.033$

Irradiated in 5\% oxygen (plus 95\% helium)

\begin{tabular}{cccccc}
$\begin{array}{c}\text { Norma motmospheric } \\
(\text { cg } 740 \text { m Hg) }\end{array}$ & 1850 & 903 & $0.49 \pm 0.016$ & 954 & $0.52 \pm 0.017$ \\
$\begin{array}{c}\text { One atmosphere } \\
\text { above normal }\end{array}$ & 950 & 583 & $0.61 \pm 0.025$ & 671 & $0.71 \pm 0.027$ \\
$\begin{array}{c}\text { Two atmospheres } \\
\text { above normal }\end{array}$ & 1000 & 683 & $0.68 \pm 0.026$ & 802 & $0.80 \pm 0.028$ \\
$\begin{array}{c}\text { Three atmospheres } \\
\text { above normal }\end{array}$ & 840 & 657 & $0.78 \pm 0.031$ & 783 & $0.93 \pm 0.033$ \\
\hline
\end{tabular}


400 r AT 50 r / MIN.

$O=5 \% \mathrm{O}_{2}$ (SUPERSCRIPTS) PRESSURES ABOVE NORMAL $\Delta=10 \% \mathrm{O}_{2}$ (SUBSCRIPTS) PRESSURES ABOVE NORMAL

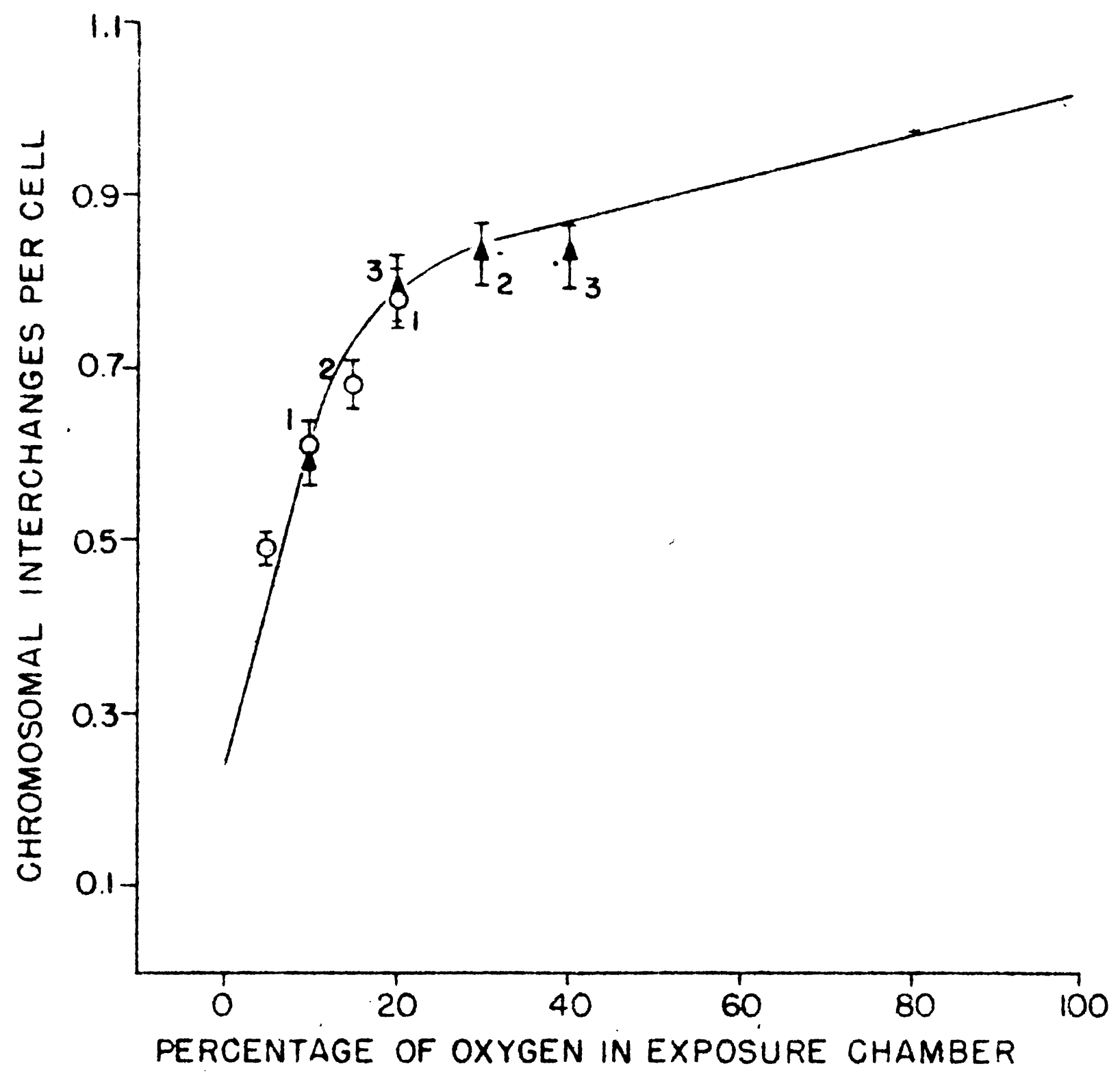

Fĩ̌. 2 
be produced by I rays in oxggenofree water $(5,6)$, it,will be recalled (Table 1) that there is still a sabstantial aberration frequency in inflorescences exposed in purffied beliran to $400 x_{0}$. The question naturally arises as to the mechanisa by which these aberrations are produced. It seoms quite probable (3) that the offect of a substarac sucla as hydrogen peroxide on aberration frequency would arise from increased production of chromosome breaks rather than from an influence on the reunion bohavior of broken ends. If this is the case, aberrations Induced by $X$ rays in the absence of oxgger might result (at least in part) from breaks produced by another substance, the OH radical, which is formed by the Iadiodecomposition of oxygerafree watero On the other hand, all the aberrations produced in the absence of oxggea might arise from the direct action of the radiation in fonizing the lecules of the chromosomes themselves. A preliminary attempt has been made to distinguls between these two possibilities by means of experiments desigaed to remore the OH radieal by promoting, during X Irradiation, the back reaction to form water. Alles (6) has shom that the presence of molecular hydrogen markedly accelorates this back reaction, Consequently, inflorescences were iro radiated in pure hydrogere at mormal atmospheric pressure and at 3 atmospheres above normal. These data are presented in Table 3o Although there is some decrease in aberration frequency compared to earlier results obtained with irradiation in beliva, the differences for the reliable observations, those of interchanges, are not sienificant. In this experiment it was not possible to obtain evidence that hydrogen was actually present in the cells during irradiation。 However, previous experiments with oxggen (2) have indicated that under similar conditions this gas diffuses into microspores very rapidiy. Thus, despite the fact that hydrogen is less solvable in water than oxygen, it seemed reasonable to conclude that a considerable amount of kydrogers would be present in the microspores during 
Table 3

The Effect of Irrediation in Brdroren on Chromosone Aberration Frequency

in Tredescontifa Marosporess $400 \mathrm{x}$ at $50 \mathrm{r} /$ Min.

\begin{tabular}{|c|c|c|c|c|c|}
\hline $\begin{array}{l}\text { Pressure in } \\
\text { exposure chamber }\end{array}$ & $\begin{array}{l}\text { Ho. } \\
\text { cells }\end{array}$ & $\begin{array}{l}\text { No. } \\
\text { interchanges }\end{array}$ & $\begin{array}{c}\text { Interchanges } \\
\text { per cell }\end{array}$ & $\begin{array}{c}\text { Interstitial } \\
\text { deletions }\end{array}$ & $\begin{array}{c}I_{0} D_{0} \\
\text { per cell }\end{array}$ \\
\hline $\begin{array}{l}\text { Normal atmosphoric } \\
(\text { ca } 740 \mathrm{mg})\end{array}$ & 707 & 149 & $0.21 \pm 0.017$ & 166 & $0.23 \pm 0.018$ \\
\hline $\begin{array}{l}\text { Three atmospheres } \\
\text { above normal }\end{array}$ & 498 & 100 & $0.20 \pm 0.020$ & 124 & $0.25 \div 0.022$ \\
\hline
\end{tabular}


Irradiation, and that this should react to remove the OH radicalo ConsequentlJ the failure to find a significant decrease in aberration frequency when $X$ radiao tion is performed in hydrogen nay nean that all the residual aberrations induced by $X$ rays in the absence of oxggen arise as a result of a direct effect of the radiation on the chromosomes. It should be pointed out, however, that this con clasion is based on the assunption that reactions leading to $\mathrm{H}_{2} \mathrm{O}_{2}$ production or suppression in cells from which oxygen has been removed as completely as possiblo are similar to those occurring in oxygenofree pure water. There is as yet little experimental evidence on this point, and it is quite possible that the complexity of the cellular enviroment may cause very different.reactions to occur.

Summary. Further studies have been made on the effect of oxggen concentrations in the range between 0 and $10 \%$ (at normel atmospheric pressure) on the frequency of X-ray-induced chronosomal aberrations in Iradescantio microspores. There is still a substantial aberration yield even in the complete (or nearly complete) absence of oxggen. When oxggen is present in irradiated cells, however, there is a rapid, Iinear increase in aberration frequency between 0 and $10 \%$ oxjgen, after which the rise is more gradual。

Experiments have also been performed to test the effect of pressure during irradiation. 1 marked increase in aberration frequency accompanying increasing pressure occurred in those experinents in which oxygen was present during irradiat10n. Exposures in 5 and $10 \%$ oxggen at different pressures up to 3 atmospheres above normal produced aberration frequencies similar to those obtained in comparable partial pressures of oxggen. These and previous results indicate that oxggen Increases the frequeney of I-ray-induced chromosone aberrations and that the anount of oxsgen present during the time of exposure determines the extent of the effect. Since no pressure effect was obtained in these experiments in the absence of oxggen, 
the apparent effect of pressure in the presence of oxygen is, in reality, an oxggen effect.

Experiments in which inflacescences were irradiated in pure hydrogen at normal atmospheric pressure and at 3 atmospheres above normal pressure showed no significant decrease in interchange frequency. These results are interpreted as supporting the view that aberrations produced by $X$ rays in the absence of oxygen may all result from a direct effect of the radiation on the chromosomes. 


\section{References}

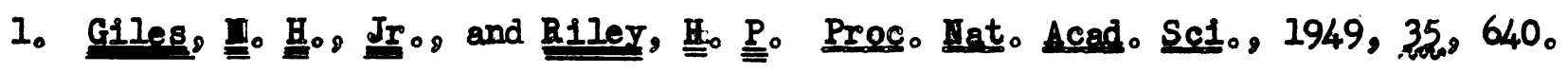

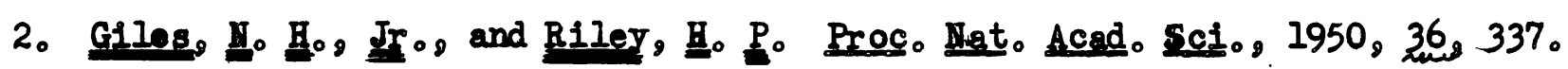

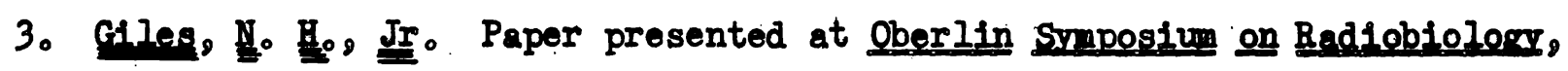
June, 1950。

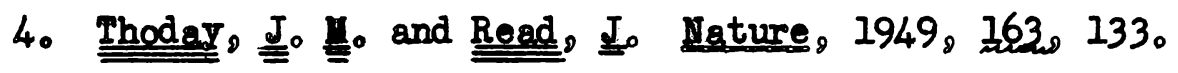

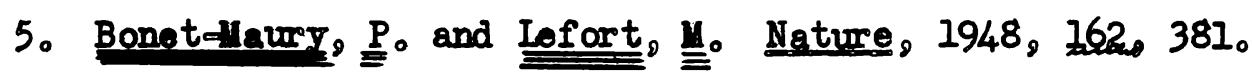

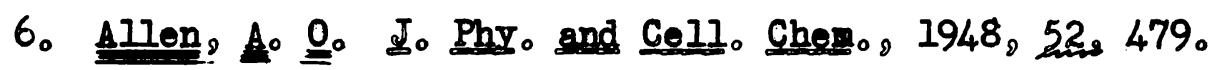



